\title{
Is Rheumatoid Arthritis Related to Coffee Consumption in Korea? A Nationwide Cross-Sectional Observational Study
}

\author{
Sang-Gyun Kim ${ }^{1,+}{ }^{\oplus}$, Jong Woo Kang ${ }^{2,3,+}$, , Seong Min Jeong ${ }^{1}{ }^{\circledR}$, Gwan Gyu Song ${ }^{2,4}$, Sung Jae Choi ${ }^{2,5}$ \\ and Jae Hyun Jung $2,5, *$ (i)
}

check for

updates

Citation: Kim, S.-G.; Kang, J.W.; Jeong, S.M.; Song, G.G.; Choi, S.J.; Jung, J.H. Is Rheumatoid Arthritis Related to Coffee Consumption in Korea? A Nationwide Cross-Sectional Observational Study. Int. J. Environ Res. Public Health 2021, 18, 7880 https://doi.org/10.3390/ ijerph18157880

Academic Editors: Ahmed A. Arif and Rajib Paul

Received: 21 June 2021

Accepted: 22 July 2021

Published: 25 July 2021

Publisher's Note: MDPI stays neutra with regard to jurisdictional claims in published maps and institutional affiliations.

Copyright: (c) 2021 by the authors. Licensee MDPI, Basel, Switzerland. This article is an open access article distributed under the terms and conditions of the Creative Commons Attribution (CC BY) license (https:// creativecommons.org/licenses/by/ $4.0 /)$
1 National Medical Center, Department of Orthopedic Surgery, 245 Eulji-ro, Jung-gu, Seoul 04564, Korea; mup81@hotmail.com (S.-G.K.); inplate@nmc.or.kr (S.M.J.)

2 Department of Medicine, Korea University College of Medicine, 73 Goryeodae-ro, Seongbuk-gu, Seoul 02841, Korea; oskang@korea.ac.kr (J.W.K.); gsong@kumc.or.kr (G.G.S.); csjmd888@korea.ac.kr (S.J.C.)

3 Department of Orthopedic Surgery, Korea University Ansan Hospital 123 Jeokgeum-ro, Danwon-gu, Ansan-si 15355, Gyeonggi-do, Korea

4 Department of Internal Medicine, Division of Rheumatology, Korea University Guro Hospital, 148 Gurodong-ro, Guro-gu, Seoul 08308, Korea

5 Department of Internal Medicine, Division of Rheumatology, Korea University Ansan Hospital, 123 Jeokgeum-ro, Danwon-gu, Ansan-si 15355, Gyeonggi-do, Korea

* Correspondence: mcfriend82@naver.com

+ These authors contributed equally to this work.

Abstract: Coffee consumption is gradually increasing in Korea. As a result, interest in the relationship between coffee consumption and various diseases is growing. Several factors affect the development of rheumatoid arthritis (RA), and coffee consumption may be related. We conducted a nationwide cross-sectional study using data from the Korea National Health and Nutrition Examination Survey (2012-2016). A total of 12,465 eligible participants (4819 men and 7646 women) were included in the study. Participants with RA were defined as those who were diagnosed and currently being treated by physicians. Daily coffee consumption amounts were categorized as none, $<1$ cup, $1-2$ cups, 2-3 cups, and $\geq 3$ cups a day based on a self-report. A multivariable logistic regression model was employed, and we calculated the odds ratios (ORs) and 95\% confidence intervals (CIs) for the odds of participants having RA with respect to coffee consumption. Compared to the no-coffee group, the ORs for RA in the $<1$ cup and 1-2 cups groups were 2.99 (95\% CI $0.33-27.28)$ and 2.63 (95\% CI 0.31-22.63) in men, respectively, and the ORs for RA for women in the <1 cup, 1-2 cups, 2-3 cups, and $\geq 3$ cups groups were 0.62 (95\% CI 0.31-1.26), 0.67 (95\% CI 0.33-1.37), 1.08 (95\% CI 0.35-3.36), and 1.43 (95\% CI 0.25-8.36), respectively. Our study concludes, therefore, that daily coffee consumption is not related to the prevalence of RA in the general Korean population.

Keywords: coffee; rheumatoid arthritis; prevalence

\section{Introduction}

Rheumatoid arthritis (RA) is a chronic inflammatory musculoskeletal disease characterized by synovitis of multiple joints causing swelling, stiffness, pain, and progressive destruction, which has a worldwide prevalence of $0.5-1.0 \%$ in adults [1]. Both genetic and environmental factors play a role in the development and progression of RA. Smoking is a representative environmental factor involved in the development of RA [1,2]. Moreover, it has been suggested that not only smoking, but various dietary factors are also associated with the development RA [3].

Coffee is one of the most commonly consumed beverages worldwide. Coffee consumption in Korea is continuously increasing, and Koreans drink approximately 12 cups of coffee per week [4]. The health effects of coffee consumption have become of increasing interest. Coffee has a protective effect against cardiovascular disease and diabetes, while it increases the risk, or shows controversial findings, with respect to musculoskeletal 
diseases such as osteoarthritis, osteoporosis, and hip fracture [5,6]. Coffee is believed to have a protective effect against the development and progression of RA by reducing $\mathrm{T}$ cell activation, $B$ cell proliferation, tumor necrosis factor (TNF)- $\alpha$ release, and increasing interleukin (IL)-10 release [7]. Previous studies have investigated the relationship between coffee consumption and RA; however, these studies were conducted with different study designs, and have shown conflicting results [8-10]. Furthermore, most previous studies on the association between coffee consumption and RA have been performed in predominantly white populations. To the best of our knowledge, there has been no studies on the relationship between coffee consumption and RA in Asians populations.

The prevalence of RA varies according to ethnicity, and coffee consumption patterns differ by geographic region [11]. In Korea, the prevalence of both RA and coffee consumption is increasing; thus, an investigation into whether coffee consumption is related to RA is believed to be a meaningful study for diet management in patients with RA [6,12]. This study investigates the relationship between coffee consumption and RA in the Korean population using nationwide data spanning five years (2012-2016) from the Korea National Health and Nutrition Examination Survey (KNHANES).

\section{Materials and Methods}

\subsection{Study Design and Setting}

This study was cross-sectional in design and used the KNHANES, which collected data for five years, between 2012 and 2016. The KNHANES is a nationwide survey administered by the Korea Centers for Disease Control and Prevention (KCDC), and the institutional review board of the KCDC gave its approval for our study [13]. The study was conducted in accordance with the Helsinki Declaration of 2000. Among the subjects selected through proportional systemic sampling, those who provided informed consent participated in the survey. Households were randomly selected for participation and sampled by multistage stratification based on geographical areas. The informed consent form given to each participant can be viewed in the KCDC database. The requirement for informed consent for this study was waived due to the fact that it performs secondary analysis based on a pre-existing KNHANES dataset.

\subsection{Participants}

In the 2012-2016 KNHANES, 12,465 participants were surveyed for both coffee consumption and RA, including 4819 men and 7646 women.

\subsection{Main Variables and Covariates}

The RA group included participants diagnosed with RA by a physician and who were currently taking medications for RA. Among the participants who responded to questionnaires about RA, those who did not have RA were defined as non-RA participants. Participants were asked how many cups of coffee they drink per day, week, and month. A cup of coffee was defined as the amount of coffee containing two teaspoons of coffee grounds. The average caffeine content in a cup of the 10 most frequently consumed coffee brands in Korea was $48.96 \pm 7.41 \mathrm{mg}$ [6]. Based on coffee consumption, participants were divided into five groups: (1) do not drink coffee, (2) drink < 1 cup of coffee per day, (3) drink 1-2 cups of coffee per day, (4) drink $2-3$ cups of coffee per day, and (5) drink $\geq 3$ cups of coffee per day.

Sex, age, body mass index (BMI), hypertension (HTN), diabetes mellitus (DM), dyslipidemia, alcohol consumption, smoking status, household income, and education level were considered as potential confounding variables affecting RA risk and coffee consumption. BMI was calculated as weight $(\mathrm{kg})$ divided by height squared $\left(\mathrm{m}^{2}\right)$. HTN was defined as an average systolic blood pressure $\geq 140 \mathrm{mmHg}$, diastolic blood pressure $\geq 90 \mathrm{mmHg}$, or use of antihypertensive medications. Prehypertension was defined as a blood pressure $\geq 120 / 80 \mathrm{mmHg}$. DM was defined as a fasting plasma glucose (FPG) level $\geq 126 \mathrm{mg} / \mathrm{dL}$, diagnosis of DM by a clinician, or use of an oral hypoglycemic agent or injected insulin. Dys- 
lipidemia was defined as follows: total cholesterol $\geq 200 \mathrm{mg} / \mathrm{dL}$, triglyceride $\geq 150 \mathrm{mg} / \mathrm{dL}$, high-density lipoprotein cholesterol $<40 \mathrm{mg} / \mathrm{dL}$ in men and $<50 \mathrm{mg} / \mathrm{dL}$ in women, or currently taking any anti-dyslipidemic drugs for controlling blood lipid concentrations. Data regarding alcohol consumption, smoking status, household income, and education level were collected during the health interviews. The participants were classified according to alcohol consumption as follows: heavy drinkers who consumed an average of $\geq 7$ units of alcohol for men and $\geq 5$ units for women $\geq 2$ days per week, moderate drinkers who consumed more than one glass of alcohol per month over the past year, and nondrinkers who never drink or drank less than one unit of alcohol per month over the past year. One unit refers to one glass, which contains approximately $10 \mathrm{~mL}$ of alcohol. The smoking status groups comprised of current, former, and non-smokers. Monthly household income was categorized into quartiles: lowest (USD < 918.3), lower middle (USD 918.3-1836.6), upper middle (USD 1836.6-3213.9), and highest (USD > 3213.9). Education level was classified as primary school or lower, middle school, high school, and university or higher.

\subsection{Statistical Analysis}

The odds ratios (ORs) and 95\% confidence intervals (95\% CIs) for RA according to coffee consumption were calculated. Sex was stratified and four different logistic regression models were used to assess the association between coffee consumption and RA. Model I was adjusted for age and BMI; model II was adjusted for age, BMI, HTN, DM, and dyslipidemia; model III was adjusted for age, BMI, HTN, DM, dyslipidemia, alcohol consumption, and smoking status; and model IV was adjusted for age, BMI, HTN, DM, dyslipidemia, alcohol consumption, smoking status, household income, and education level. The $p$-values for trends in RA according to coffee consumption were calculated using the Cochran-Armitage trend test. The multiple imputation analysis was performed for the missing data. SPSS ver. 23.0 (SPSS Inc., Chicago, IL, USA) was used for all statistical analyses, and a $p$-value $<0.05$ was considered to indicate significance.

\section{Results}

\subsection{Baseline Characteristics}

The prevalence of RA among participants in this study was $0.5 \%$ for men, $0.9 \%$ for women, and $0.8 \%$ overall. For both men and women, participants with RA were older and had lower education levels than those without RA; however, there were no significant differences in BMI, DM, dyslipidemia, alcohol consumption, smoking status, or coffee consumption. In women, the prevalence of HTN was higher in the RA group than in the non-RA group, whereas in men, the income level was lower in the RA group than in the non-RA group. The baseline characteristics of the participants with and without RA are summarized in Table 1.

The demographic characteristics of the participants according to coffee consumption are summarized in Table 2. In both men and women, the higher the consumption of coffee, the higher the percentage of drinkers and smokers, and the higher the household income and education level.

\subsection{Relationship between Coffee Consumption and Rheumatoid Arthritis}

In the crude, four multiple logistic regression models, there was no significant association between coffee consumption and RA prevalence in both men and women (Table 3). After adjusting for all variables included in the study, compared to the no-coffee group, the ORs for RA in men drinking < 1 cup and $1-2$ cups of coffee per day were 2.99 (95\% CI 0.33-27.28) and 2.63 (95\% CI 0.31-22.63), respectively. In women, the ORs for RA in the $<1$ cup, $1-2$ cups, $2-3$ cups, and $\geq 3$ cups groups were 0.62 (95\% CI $0.31-1.26), 0.67$ (95\% CI $0.33-1.37$ ), 1.08 (95\% CI 0.35-3.36), and 1.43 (CI 0.25-8.36), respectively. There were no men in the $\geq 2$ cups group in our sample of RA patients. 
Table 1. Characteristics of participants with and without rheumatoid arthritis.

\begin{tabular}{|c|c|c|c|c|c|c|}
\hline & \multicolumn{3}{|c|}{ Male $(n=4819)$} & \multicolumn{2}{|c|}{ Female $(n=7646)$} & \multirow[b]{2}{*}{$p$} \\
\hline & $\begin{array}{c}\text { RA } \\
(n=23)\end{array}$ & $\begin{array}{c}\text { Non-RA } \\
(n=4796)\end{array}$ & $p$ & $\begin{array}{c}\text { RA } \\
(n=72)\end{array}$ & $\begin{array}{c}\text { Non-RA } \\
(n=7574)\end{array}$ & \\
\hline Age (years) & $56.57 \pm 6.07$ & $43.03 \pm 12.80$ & 0.000 & $53.07 \pm 9.10$ & $43.58 \pm 12.38$ & 0.000 \\
\hline $\mathrm{BMI}\left(\mathrm{kg} / \mathrm{m}^{2}\right)$ & $23.44 \pm 2.47$ & $24.56 \pm 3.41$ & 0.102 & $23.24 \pm 3.59$ & $23.17 \pm 3.56$ & 0.967 \\
\hline HTN & & & 0.799 & & & 0.001 \\
\hline Normal & $10(43.5)$ & 2009 (41.9) & & $32(44.5)$ & $4944(65.3)$ & \\
\hline Pre-HTN & $6(26.1)$ & $1541(32.1)$ & & $24(33.3)$ & 1411 (18.6) & \\
\hline $\mathrm{HTN}$ & $7(30.4)$ & $1246(26.0)$ & & $16(22.2)$ & $1219(16.1)$ & \\
\hline $\mathrm{DM}$ & & & 0.574 & & & 0.524 \\
\hline Normal & $16(69.6)$ & 3037 (63.3) & & $57(79.2)$ & 5877 (77.6) & \\
\hline IFG & $4(17.4)$ & $1282(26.7)$ & & $13(18.1)$ & $1252(16.5)$ & \\
\hline $\mathrm{DM}$ & $3(13.0)$ & $477(10.0)$ & & $2(2.8)$ & $445(5.9)$ & \\
\hline Dyslipidemia & & & 0.391 & & & 0.811 \\
\hline No & $12(52.2)$ & $2965(61.8)$ & & $40(55.6)$ & $4345(57.4)$ & \\
\hline Yes & $11(47.8)$ & $1831(38.2)$ & & $32(44.4)$ & $3229(42.6)$ & \\
\hline Alcohol & & & 0.123 & & & 0.529 \\
\hline Non-drinker & $6(26.1)$ & $580(12.1)$ & & $25(34.7)$ & $2181(28.8)$ & \\
\hline $\begin{array}{l}\text { Moderate } \\
\text { drinker }\end{array}$ & $13(56.5)$ & $3201(66.7)$ & & $43(59.7)$ & $4984(65.8)$ & \\
\hline $\begin{array}{l}\text { Heavy } \\
\text { drinker }\end{array}$ & $4(17.4)$ & 1015 (21.2) & & $4(5.6)$ & $409(5.4)$ & \\
\hline Smoking & & & 0.074 & & & 0.714 \\
\hline Non-smoker & $3(13.0)$ & $1177(24.5)$ & & $66(91.6)$ & 6709 (88.6) & \\
\hline $\begin{array}{l}\text { Former } \\
\text { smoker }\end{array}$ & $13(56.5)$ & $1640(34.2)$ & & $3(4.2)$ & 437 (5.8) & \\
\hline $\begin{array}{l}\text { Current } \\
\text { smoker }\end{array}$ & 7 (30.5) & 1979 (41.3) & & $3(4.2)$ & $428(5.6)$ & \\
\hline Income level & & & 0.001 & & & 0.108 \\
\hline Lowest & $7(30.4)$ & $397(8.3)$ & & $12(16.7)$ & $743(9.8)$ & \\
\hline Lower middle & $5(21.7)$ & $1110(23.1)$ & & $19(26.4)$ & 1907 (25.2) & \\
\hline Upper middle & $2(8.8)$ & $1570(32.7)$ & & $15(20.8)$ & $2374(31.3)$ & \\
\hline Highest & $9(39.1)$ & 1719 (35.9) & & $26(33.7)$ & $2550(33.7)$ & \\
\hline Education level & & & 0.000 & & & 0.000 \\
\hline $\begin{array}{l}\text { Primary } \\
\text { school or lower }\end{array}$ & $6(26.1)$ & $328(6.8)$ & & $22(30.6)$ & 881 (11.6) & \\
\hline Middle school & $4(17.4)$ & $373(7.8)$ & & $13(18.1)$ & $728(9.6)$ & \\
\hline High school & $4(17.4)$ & $1878(39.2)$ & & $22(30.6)$ & $2941(38.9)$ & \\
\hline $\begin{array}{l}\text { University or } \\
\text { higher }\end{array}$ & $9(39.1)$ & $2217(46.2)$ & & 15 (20.7) & 3024 (39.9) & \\
\hline $\begin{array}{l}\text { Daily coffee } \\
\text { consumption }\end{array}$ & & & 0.418 & & & 0.836 \\
\hline None & $1(4.3)$ & 475 (9.9) & & $13(18.1)$ & $1023(13.5)$ & \\
\hline$<1$ cup & $9(39.1)$ & $1478(30.8)$ & & $25(34.7)$ & $2860(37.8)$ & \\
\hline $1-2$ cups & $13(56.6)$ & $2341(48.8)$ & & $26(36.1)$ & $2883(38.1)$ & \\
\hline $2-3$ cups & $0(0.0)$ & $382(8.0)$ & & $6(8.3)$ & $642(8.6)$ & \\
\hline$\geq 3$ cups & $0(0.0)$ & $120(2.5)$ & & $2(2.8)$ & $166(2.2)$ & \\
\hline
\end{tabular}

Values are presented as mean \pm standard deviation or number (\%). RA, rheumatoid arthritis; BMI, body mass index; HTN, hypertension; DM, diabetes mellitus; IFG, impaired fasting glucose. 
Table 2. Demographic characteristics of men (A) and women (B) according to coffee consumption.

\begin{tabular}{|c|c|c|c|c|c|c|}
\hline \multicolumn{7}{|c|}{ (A) } \\
\hline & \multicolumn{4}{|c|}{ Coffee Consumption $(n=4343)$} & \multirow{2}{*}{$\begin{array}{c}\text { No Coffee } \\
(n=476)\end{array}$} & \multirow[b]{2}{*}{$p$} \\
\hline & $\begin{array}{l}\geq 3 \text { Cups } \\
(n=120)\end{array}$ & $\begin{array}{c}\text { 2-3 Cups } \\
(n=382)\end{array}$ & $\begin{array}{l}1-2 \text { Cups } \\
(n=2354)\end{array}$ & $\begin{array}{c}<1 \text { Cup } \\
(n=1487)\end{array}$ & & \\
\hline Age (years) & $39.85 \pm 9.11$ & $40.96 \pm 11.18$ & $46.00 \pm 11.16$ & $40.94 \pm 14.27$ & $37.97 \pm 14.17$ & 0.000 \\
\hline $\mathrm{BMI}\left(\mathrm{kg} / \mathrm{m}^{2}\right)$ & $25.04 \pm 3.08$ & $24.79 \pm 3.29$ & $24.65 \pm 3.28$ & $24.48 \pm 3.61$ & $24.05 \pm 3.52$ & 0.114 \\
\hline $\mathrm{HTN}$ & & & & & & 0.079 \\
\hline Normal & $54(45.0)$ & $167(43.7)$ & $947(40.2)$ & $635(42.7)$ & $216(45.4)$ & \\
\hline Pre-HTN & $36(30.0)$ & $117(30.6)$ & $760(32.3)$ & $469(31.5)$ & $165(34.6)$ & \\
\hline HTN & $30(25.0)$ & $98(25.7)$ & $647(27.5)$ & $383(25.8)$ & $95(20.0)$ & \\
\hline $\mathrm{DM}$ & & & & & & 0.000 \\
\hline Normal & $93(77.5)$ & $256(67.0)$ & $1403(59.6)$ & $962(64.7)$ & $339(71.2)$ & \\
\hline IFG & $20(16.7)$ & $87(22.8)$ & $707(30.0)$ & $372(25.0)$ & $100(21.0)$ & \\
\hline DM & $7(5.8)$ & $39(10.2)$ & $244(10.4)$ & $153(10.3)$ & $37(7.8)$ & \\
\hline Dyslipidemia & & & & & & 0.000 \\
\hline No & $82(68.3)$ & $222(58.1)$ & $1375(58.4)$ & $980(65.9)$ & $318(66.8)$ & \\
\hline Yes & $38(31.7)$ & $160(41.9)$ & $979(41.6)$ & $507(34.1)$ & $158(33.2)$ & \\
\hline Alcohol & & & & & & 0.000 \\
\hline Non-drinker & $9(10.6)$ & $26(6.8)$ & $302(12.8)$ & $160(10.8)$ & $84(17.6)$ & \\
\hline Moderate drinker & $46(54.1)$ & $279(73.0)$ & $1543(65.5)$ & 1019 (68.5) & $288(60.5)$ & \\
\hline Heavy drinker & $30(35.3)$ & $77(20.2)$ & 509 (21.6) & $308(20.7)$ & $104(21.8)$ & \\
\hline Smoking & & & & & & 0.000 \\
\hline Non-smoker & $26(21.7)$ & $78(20.4)$ & $395(16.8)$ & $467(31.4)$ & $214(45.0)$ & \\
\hline Former smoker & $33(27.5)$ & $136(35.6)$ & 775 (32.9) & $562(37.8)$ & $147(30.8)$ & \\
\hline Current smoker & $61(50.8)$ & $168(44.0)$ & $1184(50.3)$ & $458(30.8)$ & $115(24.2)$ & \\
\hline Income level & & & & & & 0.000 \\
\hline Lowest & $7(5.8)$ & $22(5.8)$ & $164(7.0)$ & $151(10.2)$ & $60(12.6)$ & \\
\hline Lower middle & $22(18.3)$ & $70(18.3)$ & $575(24.4)$ & $337(22.7)$ & $111(23.3)$ & \\
\hline Upper middle & $38(31.7)$ & $118(30.9)$ & 789 (33.5) & $488(32.8)$ & $139(29.2)$ & \\
\hline Highest & $53(44.2)$ & $172(45.0)$ & $826(35.1)$ & $511(34.4)$ & $166(34.9)$ & \\
\hline Education level & & & & & & 0.000 \\
\hline Primary school or lower & $0(0.0)$ & $9(2.4)$ & $211(9.0)$ & $94(6.3)$ & $20(4.2)$ & \\
\hline Middle school & $4(3.4)$ & $21(5.4)$ & $216(9.2)$ & $113(7.7)$ & $23(4.8)$ & \\
\hline High school & $31(25.8)$ & $90(23.6)$ & $888(37.7)$ & $637(42.8)$ & $236(49.6)$ & \\
\hline University or higher & $85(70.8)$ & $262(68.6)$ & $1039(44.1)$ & $643(43.2)$ & $197(41.4)$ & \\
\hline RA & & & & & & 0.418 \\
\hline No & $120(100.0)$ & $382(100.0)$ & $2341(99.4)$ & 1478 (99.4) & $475(99.8)$ & \\
\hline Yes & $0(0.0)$ & $0(0.0)$ & $13(0.6)$ & $9(0.6)$ & $1(0.2)$ & \\
\hline \multicolumn{7}{|c|}{ (B) } \\
\hline & \multicolumn{4}{|c|}{ Coffee Consumption $(n=6610)$} & No Coffee & \\
\hline & $\begin{array}{l}\geq 3 \text { Cups } \\
(n=168)\end{array}$ & $\begin{array}{l}2-3 \text { Cups } \\
(n=648)\end{array}$ & $\begin{array}{l}\text { 1-2 Cups } \\
(n=2909)\end{array}$ & $\begin{array}{c}<1 \text { Cup } \\
(n=2885)\end{array}$ & $(n=1036)$ & $p$ \\
\hline Age (years) & $39.32 \pm 9.91$ & $40.92 \pm 10.42$ & $44.70 \pm 10.92$ & $44.07 \pm 13.19$ & $42.06 \pm 14.67$ & 0.000 \\
\hline $\mathrm{BMI}\left(\mathrm{kg} / \mathrm{m}^{2}\right)$ & $22.71 \pm 3.66$ & $22.99 \pm 3.56$ & $23.42 \pm 3.49$ & $23.23 \pm 3.62$ & $22.53 \pm 3.42$ & 0.000 \\
\hline HTN & & & & & & 0.000 \\
\hline Normal & $123(73.2)$ & $467(72.1)$ & $1863(64.0)$ & $1821(63.1)$ & $702(67.8)$ & \\
\hline Pre-HTN & $31(18.5)$ & $113(17.4)$ & $561(19.3)$ & $540(18.7)$ & $190(18.36)$ & \\
\hline HTN & $14(8.3)$ & 68 (10.5) & 485 (16.7) & $524(18.2)$ & 144 (11.7) & \\
\hline $\mathrm{DM}$ & & & & & & 0.001 \\
\hline Normal & 135 (80.4) & 537 (82.9) & $2251(77.42)$ & 2207 (76.5) & 804 (77.6) & \\
\hline IFG & $27(16.1)$ & $91(14.0)$ & $503(17.3)$ & 489 (16.9) & $155(15.0)$ & \\
\hline $\mathrm{DM}$ & $6(3.6)$ & $20(3.1)$ & $155(5.3)$ & $189(6.6)$ & $77(7.4)$ & \\
\hline
\end{tabular}


Table 2. Cont.

\begin{tabular}{|c|c|c|c|c|c|c|}
\hline Dyslipidemia & & & & & & 0.000 \\
\hline No & $123(73.2)$ & $414(63.9)$ & $1639(56.3)$ & $1626(56.42)$ & $583(56.3)$ & \\
\hline Yes & $45(26.8)$ & $234(36.1)$ & $1270(43.7)$ & $1259(43.6)$ & $453(43.7)$ & \\
\hline Alcohol & & & & & & 0.000 \\
\hline Non-drinker & $24(14.3)$ & $136(21.0)$ & $709(24.4)$ & $872(30.2)$ & 465 (44.9) & \\
\hline Moderate drinker & $130(77.4)$ & $472(72.8)$ & $2010(69.1)$ & $1890(65.5)$ & $525(50.7)$ & \\
\hline Heavy drinker & $14(8.3)$ & $40(6.2)$ & $190(6.5)$ & $123(4.3)$ & $46(4.4)$ & \\
\hline Smoking & & & & & & 0.000 \\
\hline Non-smoker & $127(75.6)$ & $550(84.9)$ & $2535(87.1)$ & $2628(91.1)$ & 935 (90.3) & \\
\hline Former smoker & $18(10.7)$ & $46(7.1)$ & $161(5.5)$ & $156(5.4)$ & $59(5.7)$ & \\
\hline Current smoker & $23(13.7)$ & $52(8.0)$ & $213(7.3)$ & $101(3.5)$ & $42(4.1)$ & \\
\hline Income level & & & & & & 0.000 \\
\hline Lowest & $2(1.2)$ & $34(5.2)$ & $278(9.6)$ & $316(11.0)$ & $125(12.1)$ & \\
\hline Lower middle & $27(16.1)$ & $106(16.4)$ & $729(25.1)$ & $760(26.3)$ & $304(29.3)$ & \\
\hline Upper middle & $45(26.7)$ & $183(28.2)$ & $923(31.7)$ & $924(32.0)$ & $314(30.3)$ & \\
\hline Highest & $94(56.0)$ & $325(50.2)$ & 979 (33.6) & $885(30.7)$ & $293(28.3)$ & \\
\hline Education level & & & & & & 0.000 \\
\hline Primary school or lower & $3(1.8)$ & $19(2.9)$ & $319(11.0)$ & $414(14.4)$ & $148(14.3)$ & \\
\hline Middle school & $10(6.0)$ & $25(3.9)$ & $304(10.5)$ & $296(10.3)$ & $106(10.2)$ & \\
\hline High school & $45(26.9)$ & $211(32.6)$ & $1166(40.0)$ & $1127(39.0)$ & $414(40.0)$ & \\
\hline University or higher & $110(65.5)$ & $393(60.3)$ & $1120(38.5)$ & $1048(36.3)$ & $368(35.5)$ & \\
\hline RA & & & & & & 0.836 \\
\hline No & $166(98.8)$ & $642(99.1)$ & $2883(99.1)$ & $2860(99.1)$ & $1023(98.7)$ & \\
\hline Yes & $2(1.2)$ & $6(0.9)$ & $26(0.9)$ & $25(0.9)$ & $13(1.3)$ & \\
\hline
\end{tabular}

Values are presented as mean \pm standard deviation or number (\%). BMI, body mass index; HTN, hypertension; DM, diabetes mellitus; IFG, impaired fasting glucose. RA, rheumatoid arthritis.

Table 3. ORs and 95\% CIs for RA by coffee consumption in men (A) and women (B).

\begin{tabular}{cccccccccc}
\hline & \multicolumn{10}{c}{ (A) } \\
\cline { 2 - 11 } & None & \multicolumn{1}{c}{$<$ Cup } & \multicolumn{2}{c}{ 1-2 Cups } & \multicolumn{2}{c}{ 2-3 Cups } & \multicolumn{2}{c}{$\geq$ 3 Cups } \\
\cline { 2 - 11 } & OR & OR & $\mathbf{9 5 \% ~ C I ~}$ & OR & $\mathbf{9 5 \% ~ C I ~}$ & OR & $\mathbf{9 5 \% ~ C I ~}$ & OR & $\mathbf{9 5 \% ~ C I ~}$ \\
\hline Crude & 1.00 & 2.89 & $0.37-22.89$ & 2.64 & $0.34-20.21$ & N/A & N/A & N/A & N/A \\
Model I & 1.00 & 2.30 & $0.29-18.35$ & 1.90 & $0.25-14.72$ & N/A & N/A & N/A & N/A \\
Model II & 1.00 & 2.40 & $0.30-19.37$ & 1.93 & $0.25-15.06$ & N/A & N/A & N/A & N/A \\
Model III & 1.00 & 2.78 & $0.33-23.57$ & 1.99 & $0.24-16.69$ & N/A & N/A & N/A & N/A \\
Model IV & 1.00 & 2.99 & $0.33-27.28$ & 2.63 & $0.31-22.63$ & N/A & N/A & N/A & N/A \\
\hline
\end{tabular}

(B)

\begin{tabular}{cccccccccc}
\hline & \multicolumn{2}{c}{ None } & \multicolumn{2}{c}{$<$ 1 Cup } & \multicolumn{2}{c}{ 1-2 Cups } & \multicolumn{2}{c}{ 2-3 Cups } & \multicolumn{2}{c}{$\geq$ 3 Cups } \\
\cline { 2 - 11 } & OR & OR & $\mathbf{9 5 \% ~ C I ~}$ & OR & $\mathbf{9 5 \% ~ C I ~}$ & OR & $\mathbf{9 5 \% ~ C I ~}$ & OR & $\mathbf{9 5 \% ~ C I ~}$ \\
\hline Crude & 1.00 & 0.69 & $0.35-1.35$ & 0.71 & $0.36-1.39$ & 0.74 & $0.28-1.95$ & 0.95 & $0.21-4.24$ \\
Model I & 1.00 & 0.71 & $0.36-1.40$ & 0.73 & $0.37-1.44$ & 1.02 & $0.37-2.80$ & 1.40 & $0.30-6.58$ \\
Model II & 1.00 & 0.68 & $0.34-1.36$ & 0.69 & $0.34-1.37$ & 0.98 & $0.36-2.72$ & 1.41 & $0.29-6.78$ \\
Model III & 1.00 & 0.62 & $0.30-1.24$ & 0.65 & $0.32-1.33$ & 0.92 & $0.33-2.61$ & 1.34 & $0.27-6.68$ \\
Model IV & 1.00 & 0.62 & $0.31-1.26$ & 0.67 & $0.33-1.37$ & 1.08 & $0.35-3.36$ & 1.43 & $0.25-8.36$ \\
\hline
\end{tabular}

Model I: adjusted for age and BMI. Model II: adjusted for age, BMI, HTN, DM, and dyslipidemia. Model III: adjusted for age, BMI, HTN, DM, dyslipidemia, alcohol consumption, and smoking status. Model IV: adjusted for age, BMI, HTN, DM, dyslipidemia, alcohol consumption, smoking status, and socioeconomic status. OR, odds ratio; CI, confidence interval; RA, rheumatoid arthritis; BMI, body mass index; HTN, hypertension; DM, diabetes mellitus.

\section{Discussion}

This study investigated the relationship between coffee consumption and RA, showing that coffee consumption was not related to the prevalence of RA in the Korean population. This is the first study on the relationship between coffee consumption and RA in the Asian 
population and considers various confounding factors, including smoking history, which critically affects the development of RA. Smoking adversely affects RA in various ways, including affecting the production of rheumatoid factor (RF), anti-citrullinated protein antibodies (ACPA), and causing oxidative stress [2]. Smoking is associated with ACPA production only in RA patients who carry the shared epitope as the human leukocyte antigen-DRB1-encoded 5-amino acid sequence motif [14]. However, there was no significant association between smoking status and RA prevalence, which may stem from the low prevalence of smoking amongst our female patients. Due to the cross-sectional design of the study, it suggested that the male participants diagnosed with RA might to have quit smoking. In addition, the possibility exists that there are fewer RA patients in Korean who carry the RA shared epitope. In this study, the higher the coffee consumption, the greater the number of cigarettes smoked, suggesting that Koreans usually smoke while drinking coffee. The lower the socioeconomic status (household income or education), the higher the prevalence of RA; however, the higher the socioeconomic status, the higher the coffee consumption. In addition, there were differences in the prevalence of chronic diseases (DM, HTN, and dyslipidemia) according to the degree of coffee consumption in this study, and these chronic diseases can affect the prevalence of RA [15]. Since there are various confounding factors between coffee consumption and the risk of RA, we adjusted for possible confounding factors in this study; however, other factors not included in this study may also have affected the associations between RA and coffee consumption.

Coffee contains more than 800 ingredients, with caffeine as the main compound. Caffeine acts as an antagonist to the $A_{1}$ and $A_{2 A}$ subtypes of the four adenosine receptors $\left(A_{1}\right.$, $A_{2 A}, A_{2 B}$, and $A_{3}$ ) [16]. Adenosine inhibits inflammation through these receptors and inhibits the production of cytokines, such as TNF- $\alpha$, IL-1, and IL-6 [17,18]. In particular, $\mathrm{A}_{2 \mathrm{~A}}$ receptors induce deactivation and apoptosis in T cells [18]. Therefore, caffeine may increase the risk of RA as a mechanism. In addition to caffeine, other major components of coffee, including cafestol, kahweol, chlorogenic acid, and furans, have anti-inflammatory and antioxidant properties $[19,20]$. Free radicals oxidize blood vessel walls, protein molecules, deoxyribonucleic acid (DNA), carbohydrates, and lipids, resulting in various human diseases [20]. RA has also been associated with oxidative stress. Oxidative stress increases the expression of pro-inflammatory cytokines and the production of RF, ACPA, and metalloproteinases, and causes damage to DNA, resulting in the development and progression of RA [21]. Unlike other studies, in this study, coffee consumption was not significantly associated with RA, and men who drank more than two cups, and women who drank three cups of coffee, did not show a greater likelihood of having RA. Since the contents and ingredients are different for each type of coffee bean, the anti-inflammatory and antioxidant effects may act differently. The most widely consumed coffees are Arabica and Robusta. Two-thirds of the coffee consumed in Korea was Arabica, and one-third was Robusta. Robusta coffee had a superior effect on lipid profile and adiponectin level to that of Arabica coffee [22], and lipid metabolism is related to inflammation, potentially explaining the absence of association between coffee and the high prevalence of RA in Korea, unlike previous observational studies in Western countries. In addition, residues of solvents (benzene, trichloroethylene, carbon tetrachloride, acetone, ammonium hydroxide, sulfuric acid, ethyl acetate, and methylene chloride) used in the process of extracting caffeine from coffee for decaffeinated coffee might have influenced the development of RA. Many of these solvents have been known to affect a number of connective tissue diseases, including RA, scleroderma, and systemic lupus erythematosus [23]. However, the effects of these solvents may have been minimized in our study because decaffeinated coffee is rarely consumed in Korea [24].

Mendelian randomization studies have shown that there was no causal relationship between coffee consumption and RA [25], which is consistent with our findings. Various factors such as coffee type, roasting method, and coffee drinking habits are related to health factors; thus, more detailed and controlled studies investigating coffee and health factors, in addition to one's genes, are needed. Despite the difficulty in researching the type, amount, 
and habits of coffee consumption, this study has several strengths. This study evaluated the relationship between coffee consumption and RA in Korea by analyzing authoritative nationwide data. In addition, our results were sequentially adjusted for various possible confounding factors, including smoking, chronic diseases, and socioeconomic status.

This study also had some limitations. First, a causal relationship could not be determined because of the study's cross-sectional design. Second, the definitions of RA and coffee consumption were based on self-reports. Consequently, these data may have been influenced by systematic errors in individuals' consideration, which may have led to non-differential misclassification or overestimation. In particular, the presence of RF and ACPA may affects the diagnosis of RA and the relationship between RA and coffee [26], which has not been investigated in this study. Third, although this study classified coffee consumption based on the number of cups of coffee consumed per day, cup size, strength, and concentration of coffee may vary considerably. Fourth, there has been no investigation of other foods that may affect the risk of RA, such as fish, fruit, vegetables, and tea [27]. Finally, the small number of RA patients in our study may not have revealed the significant relationship; thus, a larger-scale study is needed. However, such a large-scale prospective study for investigating the relationship between coffee consumption and the prevalence of a disease is not realistic due to the difficulties in recruiting and retaining such a large number of participants.

\section{Conclusions}

The present study demonstrated that the prevalence of RA was not associated with coffee consumption in the general Korean population. This is the first Asian study on the relationship between coffee consumption and RA. However, since various factors affect the relationship between coffee consumption and RA, attention should be paid to interpretation, and further studies and intervention trials should be conducted.

Author Contributions: Conceptualization, S.-G.K., J.W.K. and J.H.J.; methodology, S.-G.K., J.W.K. and J.H.J.; software, S.-G.K. and J.W.K.; validation, S.-G.K., J.W.K. and J.H.J.; formal analysis, S.-G.K., J.W.K. and S.M.J.; investigation, S.-G.K., J.W.K., S.M.J., G.G.S. and S.J.C.; resources, S.M.J., G.G.S. and S.J.C.; data curation, S.-G.K., J.W.K. and S.M.J.; writing-original draft preparation, S.-G.K. and J.W.K.; writing—review and editing, S.M.J., G.G.S., S.J.C. and J.H.J.; visualization, G.G.S., S.J.C. and J.H.J.; supervision, J.H.J.; project administration, S.-G.K., J.W.K. and J.H.J.; funding acquisition, J.W.K. All authors have read and agreed to the published version of the manuscript.

Funding: This research was supported by the Basic Science Research Program through the National Research Foundation of Korea, funded by the Ministry of Education, grant number 2019R1I1A1A01041847.

Institutional Review Board Statement: The study was conducted according to the guidelines of the Declaration of Helsinki, and approved by the Institutional Review Board (IRB) of the Korea Centers for Disease Control and Prevention (IRB number: 2012-01EXP-01-2C, 2013-07CON-03-4C, and 2013-12EXP-03-5C).

Informed Consent Statement: Informed consent was obtained from all subjects involved in the study.

Data Availability Statement: All National Health and Nutrition Examination Survey files are available from the Korea Centers for Disease Control and Prevention database (URL https:/ / knhanes.cdc. go.kr/knhanes/sub03/sub03_02_02.do, accessed on 18 September 2020).

Conflicts of Interest: The authors declare no conflict of interest.

\section{References}

1. Aletaha, D.; Smolen, J.S. Diagnosis and management of rheumatoid arthritis: A review. JAMA 2018, 320, 1360-1372. [CrossRef] [PubMed]

2. Ishikawa, Y.; Terao, C. The impact of cigarette smoking on risk of rheumatoid arthritis: A narrative review. Cells $2020,9,475$. [CrossRef] [PubMed]

3. Pattison, D.J.; Harrison, R.A.; Symmons, D.P. The role of diet in susceptibility to rheumatoid arthritis: A systematic review. J. Rheumatol. 2004, 31, 1310-1319. 
4. Jung, J.H.; Seok, H.; Choi, S.J.; Kim, C.; Bang, C.H.; Song, G.G. Relationship between coffee consumption and serum uric acid level in the general Korean population: A nationwide cross-sectional study. Int. J. Rheum. Dis. 2020, 23, 420-427. [CrossRef] [PubMed]

5. Nieber, K. The impact of coffee on health. Planta Med. 2017, 83, 1256-1263. [CrossRef] [PubMed]

6. Bang, C.H.; Kim, C.; Kim, J.H.; Choi, S.J.; Song, G.G.; Jung, J.H. Is knee osteoarthritis related to coffee drinking? A nationwide cross-sectional observational study. Clin. Rheumatol. 2019, 38, 817-825. [CrossRef] [PubMed]

7. Sharif, K.; Watad, A.; Bragazzi, N.L.; Adawi, M.; Amital, H.; Shoenfeld, Y. Coffee and autoimmunity: More than a mere hot beverage! Autoimmun. Rev. 2017, 16, 712-721. [CrossRef]

8. Heliövaara, M.; Aho, K.; Knekt, P.; Impivaara, O.; Reunanen, A.; Aromaa, A. Coffee consumption, rheumatoid factor, and the risk of rheumatoid arthritis. Ann. Rheum. Dis. 2000, 59, 631-635. [CrossRef] [PubMed]

9. Karlson, E.W.; Mandl, L.A.; Aweh, G.N.; Grodstein, F. Coffee consumption and risk of rheumatoid arthritis. Arthritis Rheum. 2003, 48, 3055-3060. [CrossRef] [PubMed]

10. Rambod, M.; Nazarinia, M.; Raieskarimian, F. The impact of dietary habits on the pathogenesis of rheumatoid arthritis: A case-control study. Clin. Rheumatol. 2018, 37, 2643-2648. [CrossRef] [PubMed]

11. McBurney, C.A.; Vina, E.R. Racial and ethnic disparities in rheumatoid arthritis. Curr. Rheumatol. Rep. 2012, $14,463-471$. [CrossRef]

12. Won, S.; Cho, S.K. Update on the prevalence and incidence of rheumatoid arthritis in Korea and an analysis of medical care and drug utilization. Rheumatol. Int. 2018, 38, 649-656. [CrossRef]

13. Kweon, S.; Kim, Y.; Jang, M.; Kim, Y.; Kim, K.; Choi, S.; Chun, C.; Khang, Y.H.; Oh, K. Data resource profile: The Korea national health and nutrition examination survey (KNHANES). Int. J. Epidemiol. 2014, 43, 69-77. [CrossRef] [PubMed]

14. Linn-Rasker, S.P.; van der Helm-van Mil, A.H.M.; van Gaalen, F.A.; Kloppenburg, M.; de Vries, R.R.P.; le Cessie, S.; Breedveld, F.C.; Toes, R.E.M.; Huizinga, T.W. Smoking is a risk factor for anti-CCP antibodies only in rheumatoid arthritis patients who carry HLA-DRB1 shared epitope alleles. Ann. Rheum. Dis. 2006, 65, 366-371. [CrossRef]

15. Abella, V.; Scotece, M.; Conde, J.; López, V.; Lazzaro, V.; Pino, J.; Gómez-Reino, J.J.; Gualillo, O. Adipokines, metabolic syndrome and rheumatic diseases. J. Immunol. Res. 2014, 2014, 343746. [CrossRef]

16. Higdon, J.V.; Frei, B. Coffee and health: A review of recent human research. Crit. Rev. Food Sci. Nutr. 2006, 46, 101-123. [CrossRef] [PubMed]

17. Bouma, M.G.; Stad, R.K.; van den Wildenberg, F.A.; Buurman, W.A. Differential regulatory effects of adenosine on cytokine release by activated human monocytes. J. Immunol. 1994, 153, 4159-4168. [PubMed]

18. Ullah, F.; Ali, T.; Ullah, N.; Kim, M.O. Caffeine prevents d-galactose-induced cognitive deficits, oxidative stress, neuroinflammation and neurodegeneration in the adult rat brain. Neurochem. Int. 2015, 90, 114-124. [CrossRef]

19. Islam, M.T.; Tabrez, S.; Jabir, N.R.; Ali, M.; Kamal, M.A.; da Silva Araujo, L.; De Oliveira Santos, J.V.; Da Mata, A.M.O.F.; De Aguiar, R.P.S.; de Carvalho Melo Cavalcante, A.A. An insight into the therapeutic potential of major coffee component. Curr. Drug Metab. 2018, 19, 544-556. [CrossRef]

20. Yashin, A.; Yashin, Y.; Wang, J.Y.; Nemzer, B. Antioxidant and antiradical activity of coffee. Antioxidants 2013, 2, 230-245. [CrossRef]

21. da Fonseca, L.J.S.; Nunes-Souza, V.; Goulart, M.O.F.; Rabelo, L.A. Oxidative stress in rheumatoid arthritis: What the future might hold regarding novel biomarkers and add-on therapies. Oxid. Med. Cell. Longev. 2019, 2019, 7536805. [CrossRef] [PubMed]

22. Shokouh, P.; Jeppesen, P.B.; Christiansen, C.B.; Mellbye, F.B.; Hermansen, K.; Gregersen, S. Efficacy of arabica versus robusta coffee in improving weight, insulin resistance, and liver steatosis in a rat model of type-2 diabetes. Nutrients 2019, 11, 2074. [CrossRef]

23. Lamichhane, D.; Collins, C.; Constantinescu, F.; Walitt, B.; Pettinger, M.; Parks, C.; Howard, B.V. Coffee and tea consumption in relation to risk of rheumatoid arthritis in the women's health initiative observational cohort. J. Clin. Rheumatol. 2019, 25, 127-132. [CrossRef] [PubMed]

24. Kim, H.J.; Cho, S.; Jacobs, D.R., Jr.; Park, K. Instant coffee consumption may be associated with higher risk of metabolic syndrome in Korean adults. Diabetes Res. Clin. Pract. 2014, 106, 145-153. [CrossRef] [PubMed]

25. Bae, S.C.; Lee, Y.H. Coffee consumption and the risk of rheumatoid arthritis and systemic lupus erythematosus: A Mendelian randomization study. Clin. Rheumatol. 2018, 37, 2875-2879. [CrossRef]

26. Lee, Y.H.; Bae, S.C.; Song, G.G. Coffee or tea consumption and the risk of rheumatoid arthritis: A meta-analysis. Clin. Rheumatol. 2014, 33, 1575-1583. [CrossRef] [PubMed]

27. Salliot, C.; Nguyen, Y.; Boutron-Ruault, M.C.; Seror, R. Environment and lifestyle: Their influence on the risk of RA. J. Clin. Med. 2020, 9, 3109. [CrossRef] 